\title{
Effects of maternal high fat intake during pregnancy and lactation on total cholesterol and adipose tissue in neonatal rats
}

\author{
M. S. Lima ${ }^{a}$, G. S. Perez ${ }^{a}$, G. L. Morais ${ }^{a}$, L. S. Santos ${ }^{a}$, G. S. Cordeiro ${ }^{a}$, R. D. Couto ${ }^{b}$, \\ T. C. B. J. Deiró ${ }^{\prime}$, C. G. Leandro ${ }^{d}$ and J. M. Barreto-Medeiros ${ }^{c}$
}

aPrograma de Pós-graduação em Alimentos, Nutrição e Saúde, Escola de Nutrição, Universidade Federal da Bahia - UFBA, Av. Araújo Pinho, 32, Canela, CEP 40110-150, Salvador, BA, Brazil

'Departamento de Análises Clínicas e Toxicológicas, Faculdade de Farmácia, Universidade Federal da Bahia - UFBA, Rua Barão de Jeremoabo, s/n, Ondina, CEP 41170-290, Salvador, BA, Brazil

'Programa de Pós-graduação em Alimentos, Nutrição e Saúde, Escola de Nutrição, Departamento de Ciências da Nutrição, Universidade Federal da Bahia - UFBA, Av. Araújo Pinho, 32, Canela, CEP 40110-150, Salvador, BA, Brazil

dDepartamento de Educação Física e Ciência do Esporte, Universidade Federal de Pernambuco - UFPE, Rua Alto do Reservatório, Bela Vista, CEP 55608-680, Vitória de Santo Antão, PE, Brazil

*e-mail: michelelima_nut@hotmail.com

Received: July 18, 2016 - Accepted: August 24, 2017 - Distributed: November 30, 2018

(With 2 figures)

\begin{abstract}
Aim: Obesity during pregnancy is one of the most established risk factors for negative long-term programming. The aim of the present study was to investigate the effects of maternal consumption of a high-fat diet during pregnancy and lactation on the weight gain, visceral adipose tissue and cholesterolemia in neonatal rats. Methods: Wistar rats were divided into two groups according to the mother's diet during pregnancy and lactation: Control group $(\mathrm{CG}, \mathrm{n}=12)$ were the offspring of rats fed a standard diet (4\% lipid) and the Test group (TG, $n=12$ ) were pups rats fed on a high fat $\operatorname{diet}(23 \%$ lipid). The weight of the animals was measured on alternate days until the 22 nd day of life, when collected visceral adipose tissue and blood were collected for biochemical analysis. For statistical analysis the Student $\mathrm{t}$ test, Sidak's teste and two way ANOVA was used, with $\mathrm{p}<0.05$. Results: the test group showed differences in weight gain, visceral adipose tissue and higher cholesterol. Conclusion: a maternal exposure to a high-fat diet during pregnancy and lactation can promote changes in weight gain, hypercholesterolemia and an increase in adipose tissue in neonatal rats.
\end{abstract}

Keywords: high fat diet, neonatal rats, cholesterol, visceral adipose tissue.

\section{Efeitos do consumo materno de dieta hiperlipídica durante a gestação e lactação no colesterol total e tecido adiposo de ratos neonatos}

\section{Resumo}

Objetivo: A obesidade durante a gestação é um dos fatores de risco mais estabelecidos para uma programação negativa em longo prazo. O objetivo do presente estudo foi investigar os efeitos do consumo materno de uma dieta hiperlipídica durante a gestação e lactação no aumento do peso, do tecido adiposo visceral e colesterolemia em ratos neonatos. Métodos: Ratos Wistar foram divididos em dois grupos de acordo com a dieta da mãe durante a gestação e lactação: grupo controle $(\mathrm{GC}, \mathrm{n}=12$ ) composto por filhotes de ratas alimentadas com uma dieta padrão (lipídios 4\%) e o grupo teste (GT, $\mathrm{n}=12$ ) composto de filhotes de ratas alimentadas com dieta hiperlipídica (lipídios 23\%). O peso dos animais foi aferido em dias alternados até o $22^{\circ}$ dia de vida, quando foi coletado sangue para análises bioquímicas. Para a análise estatística utilizou-se os seguintes testes: two way ANOVA, teste de Sidak e teste t de Student, com p<0,05. Resultados: O grupo teste mostrou diferença no ganho de peso, no tecido adiposo visceral e nos níveis de colesterol. Conclusão: Uma exposição materna a uma dieta hiperlipídica durante a gestação e lactação pode promover maior ganho ponderal, hipercolesterolemia e um aumento do tecido adiposo em ratos neonatos.

Palavras-chave: dieta hiperlipídica, ratos neonatos, colesterol, tecido adiposo visceral.

\section{Introduction}

The intake of fats, especially saturated fat and refined foods, have increased throughout the world (Guthrie et al., 2002). This dietary pattern is characterized by high palatability food with a high concentration of calories, fat and sugar. It is known as a westernized diet, fast food or cafeteria diet (Sampey et al., 2011). It emerged in the second half of the 
twentieth century when the convenience and quickly eating became popular and today it represents a global food pattern.

The consumption of high-fat diets for young women of reproductive age has been growing (IASO, 2013). The increased prevalence of obesity and its complications in this population, especially during pregnancy and lactation has raised concerns about the effects on the health of offspring caused by an imbalance in the supply of nutrients in the development phase (Oben et al., 2010; Barker, 1991).

Epigenetic mechanisms have been associated with metabolic imprinting of and damages to adulthood offspring (Waterland, 2005; Sullivan and Grove, 2010). In our previous studies it was shown that malnutrition during pregnancy and lactation can promote lasting effects on the offspring (Barreto-Medeiros et al., 2007; Melo et al., 2011). We also found in previous studies that maternal intake of high fat diet, promoting hypercholesterolemia (Oliveira et al., 2011; Perez et al., 2015), increased visceral fat and hepatic steatosis in rats in adulthood (Perez et al., 2015).

Thus, it is of great interest to know the early consequences of the consumption of a high fat a high glycemic index diet during the perinatal period. This study aims to investigate the early effects of maternal consumption of high fat diet on body weight gain, cholesterolemia and visceral adipose tissue in neonatal rats.

\section{Material and Methods}

\subsection{Animals}

All the procedures involving animals were approved by the Animal Research Ethics Committee of the Federal University of Bahia, protocol no. 20/10. The animals were kept under stable temperature conditions with a 12-hour light-dark cycle. Unrelated, primiparous Wistar rats, 90-100 days old, were mated with non-consanguineous males (2:1 ratio). Pregnancy was confirmed by means of the vaginal smear test, in which the presence of spermatozoa in the vaginal secretion was considered indicative of the onset of pregnancy.

\subsection{Experimental groups}

After confirmation of pregnancy, the rats were allocated to two experimental groups based on the diet to be given during pregnancy and lactation: Control group $(\mathrm{C}, \mathrm{n}=12)$, offspring whose mothers received a standard commercial diet for rats; The high-fat group $(\mathrm{H}, \mathrm{n}=12)$ were the offspring whose mothers received the high fat diet. The period up to 24 hours after birth was considered to adjust the baby rats per litter of six rats.

\subsection{Diets}

The control diet was a standard commercial diet for rats (Nuvilab ${ }^{\circledR} \mathrm{CR} 1$ ) containing approximately $22.0 \%$ protein, $57.0 \%$ carbohydrates, $4 \%$ fat, corresponding to approximately $3.5 \mathrm{kcal} / \mathrm{g}$. The high-fat diet consisted of a mixture of hypercaloric foods, including the commercial diet $\left(\mathrm{Nuvilab}^{\circledR}\right)$, roasted peanuts, milk chocolate and biscuits, containing $17.0 \%$ protein, $46.0 \%$ carbohydrates, $23 \%$ fat, corresponding to $4.5 \mathrm{kcal} / \mathrm{g}$ (Oliveira et al., 2011). The rats kept the consumption of diets throughout the period of pregnancy and lactation. Until the 21 st day of life, the animals continued exposed to same diet.

\subsection{Body weight}

This was recorded throughout lactation (day 2 to 22). The relative body weight gain was calculated as the percentage gain in relation to their weight on the initial day (daily weight / initial weight $* 100$ ).

\subsection{Visceral adipose tissue}

At 22 days of age, the animals were anesthetized (0.5 mL xylazine and $2.0 \mathrm{~mL}$ ketamine in normal saline, final volume $10 \mathrm{~mL} ; 0.1 \mathrm{~mL}$ anesthetic solution $/ 10 \mathrm{~g}$ body weight) and killed using the cardiac puncture technique. A longitudinal incision was made in the abdomen to dissect the visceral adipose tissue. This tissue was then weighed on a digital electronic scale (Marte ${ }^{\circledR}$ model S-400) with a 4-kg capacity and a 0.001-g sensitivity.

\subsection{Total cholesterol}

The blood was collected by cardiac puncture technique and centrifuged to separate the plasma fraction. The levels of total cholesterol were measured at a specialized veterinary laboratory by means of enzymatic methods using a commercial kit (Biosystems, Spain) and an A25 Clinical Chemistry Analyser ${ }^{\circledR}$.

\subsection{Statistical analysis}

Results are presented as means \pm standard errors of the mean. Data for all analyses were performed using the statistical GraphPadPrism version 6.04 software for Windows. For statistical analysis of body weight a two-way ANOVA was used. When the ANOVA indicated a significant difference, Sidak's test was used to identify the differences between groups. For total cholesterol and visceral adipose tissue, the $\mathrm{T}$ test was used to compare groups. The significance level was set to $5 \%$ in all the analyses.

\section{Results}

Weight gain in the high fat group was higher than Control from $18^{\text {th }}$ day (see Figure 1) to weaning. The high fat diet raised the total cholesterol (Figure 2a) and visceral adipose tissue of the offspring at 22 days of life (as shown in Figure 2b).

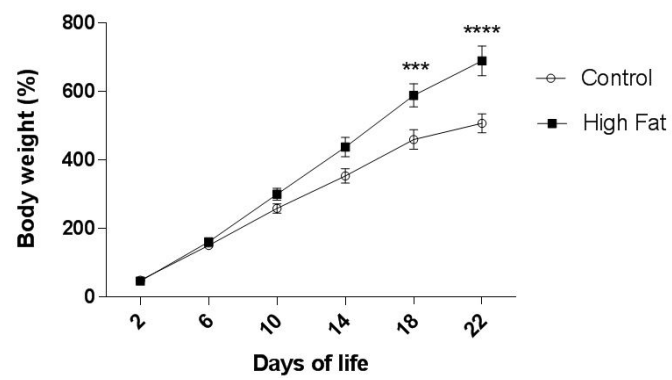

Figure 1. Body weight gain during lactation of control group $(\mathrm{C})$ or high fat group $(\mathrm{H})$. The values are presented as mean \pm SEM, using Two-way ANOVA followed by Sidak's multiple comparison test. Significance level $* * * p<0.001$; $* * * * \mathrm{p}<0.0001$ 
a

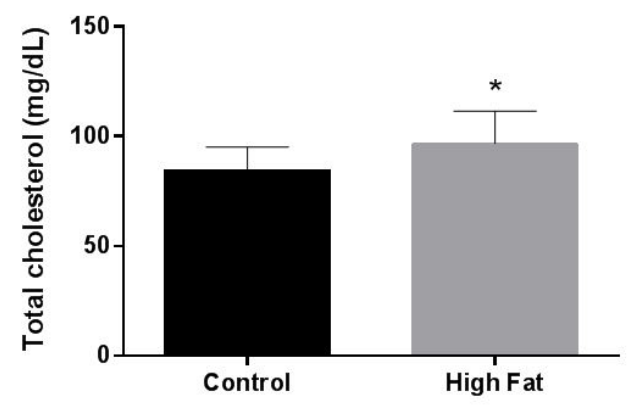

b

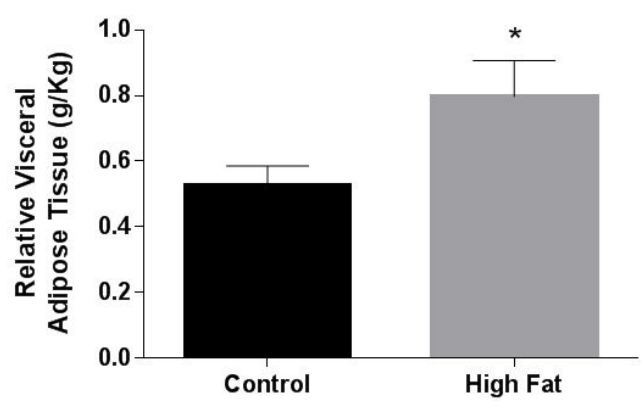

Figure 2. Total cholesterol of offspring from control group (C) or high fat group $(\mathrm{H})$ at 22 days of life (a). Relative weight of the visceral adipose tissue of offspring from control group high fat group at 22 days of life (b). The results are expressed as the means \pm SEM as calculated by $\mathrm{T}$ test. Significance level: $* \mathrm{p}<0.05$.

\section{Discussion}

Given the increasing prevalence of obesity (WHO, 2014), understanding how obesity in a mother might impact her children's health is of major public health importance. In this study, we demonstrate the early effects of maternal diet in the phenotype of their offspring at 22-days of life.

During the period of lactation, the rats whose mothers were fed with high fat diet had a higher body weight gain compared to controls. Similar results were found by (Desai et al., 2014; Tamashiro et al., 2009; Purcell et al., 2011).

The influence of maternal diet on milk composition may explain the results. Confirming this hypothesis, studies have shown that the quality of maternal dietary lipids consumed during lactation is correlated to the nutritional profile secreted of milk (Bautista et al., 2016; Oosting et al., 2015). According to Purcell et al. (2011), on the 10th day, the milk of rats fed with a high fat diet becomes more caloric and high in fat. Likewise, Del Prado et al. (1997) studied the composition of rats' milk fed on a high fat diet and found that the amount of lipid and total calories were significantly higher than the controls, and therefore this can contribute to greater weight gain.
Another important aspect to consider is the amount ingested of milk. Previous work has shown that young rats fed a high fat diet consume more breast milk (Purcell et al., 2011). Thus, a higher milk intake may also have contributed to the results.

The maternal high fat diet also increased the visceral adiposity of neonatal rats and the serum cholesterol. An important result because nowadays fat cells are not only seen as reserve, protection and support structures, but as a real organ with intense endocrine and metabolic activity (Hauner, 2004), participating in weight control mechanisms and involved in the onset of cardiovascular complications and hypertension in individuals with excess visceral adiposity (Abraham et al., 2015).

The nutritional composition of the diet given to the rats, particularly the amount of saturated fatty acids may have contributed to these results. In a previously study, Oliveira et al. (2011) showed that this high fat diet has $23 \%$ of fat and $41.71 \%$ of these lipids are saturated fatty acids, more than twice that found in the control diet (19.17\%). According to Tinoco et al. (2007), the milk fatty acid profile of mothers who consume a high fat diet resembles the profile of maternal diet. Thus, the composition of fatty acids in milk may have contributed to the rise in cholesterol levels of the offspring.

In summary, our data in a rat model demonstrate that maternal exposure to high fat diet causes overweight, increased visceral adiposity and hypercholesterolemia in neonatal rats, providing further evidence regarding the paramount importance of a balanced diet in the critical periods of development. Nutritional recommendations on obesity must therefore target maternal and postnatal nutrition, especially with regard to fatty acid composition.

\section{Acknowledgements}

The present study was conducted with the financial support of the National Program of Academic Cooperation (Programa Nacional de Cooperação Acadêmica PROCAD)/CAPES (Brazilian Federal Agency for Support and Evaluation of Graduate Education - Coordenação de Aperfeiçoamento de Pessoal de Nível Superior) and National Counsel of Technological and Scientific Development (Conselho Nacional de Desenvolvimento Científico e Tecnológico - CNPq).

\section{References}

ABRAHAM, T.M., PEDLEY,A., MASSARO, J.M., HOFFMANN, U. and FOX, C.S., 2015. Association between visceral and subcutaneous adipose depots and incident cardiovascular disease risk factors. Circulation, vol. 132, no. 17, pp. 1639-1647. PMid:26294660. http://dx.doi.org/10.1161/CIRCULATIONAHA.114.015000.

BARKER, D.J., 1991. The intrauterine origins of cardiovascular and obstructive lung disease in adult life. The Marc Daniels Lecture 1990. Journal of the Royal College of Physicians of London, vol. 25, no. 2, pp. 129-133. PMid:2066923.

BARRETO-MEDEIROS, J.M., QUEIRÓS-SANTOS, A., CABRAL-FILHO, J.E., SILVA, W.T.F., LEANDRO, C.G., 
DEIRÓ, T.C., MANHAES-DE-CASTRO, R. and BARBOSADE-CASTRO, C.M.M., 2007. Stress/aggressiveness-induced immune changes are altered in adult rats submitted to neonatal malnutrition. Neuroimmunomodulation, vol. 14, no. 5, pp. 229334. PMid:18073497. http://dx.doi.org/10.1159/000112047.

BAUTISTA, C.J., MONTANO, S., RAMIREZ, V., MORALES, A., NATHANIELSZ, P.W., BOBADILLA, N.A. and ZAMBRANO, E., 2016. Changes in milk composition in obese rats consuming a high-fat diet. British Journal of Nutrition, vol. 115, no. 3, pp. 538-546. PMid:26608475. http://dx.doi.org/10.1017/S0007114515004547.

DEL PRADO, M., DELGADO, G. and VILLALPANDO, S., 1997. Maternal lipid intake during pregnancy and lactation alters milk composition and production and litter growth in rats. The Journal of Nutrition, vol. 127, no. 3, pp. 458-462. PMid:9082030.

DESAI, M., JELLYMAN, J.K., HAN, G., BEALL, M., LANE, R.H., ROSS, M.G., 2014. Maternal obesity and high-fat diet program offspring metabolic syndrome. American Journal of Obstetrics and Gynecology, vol. 211, no. 3, pp. 237.e1-237.e13.

GUTHRIE, J.F., LIN, B.H. and FRAZAO, E., 2002. Role of food prepared away from home in the American diet, $1977-78$ versus 1994-96: changes and consequences. Journal of Nutrition Education and Behavior, vol. 34, no. 3, pp. 140-150. PMid:12047838. http:// dx.doi.org/10.1016/S1499-4046(06)60083-3 .

HAUNER, H., 2004. The new concept of adipose tissue function. Physiology \& Behavior, vol. 83, no. 4, pp. 653-658. PMid:15621071. http://dx.doi.org/10.1016/j.physbeh.2004.09.016.

INTERNATIONAL SOCIETY FOR THE STUDY OF OBESITY - IASO, 2013 [viewed 10 June 2015]. Prevalence of overweight and obesity around the globe. Available from: http://www.iaso. org/resources/obesity-data-portal/resources/tables/

MELO, J.F., ALOULOU, N., DUVAL, J.L., VIGNERON, P., BOURGOIN, L., LEANDRO, C.G., DE CASTRO, C.M. and NAGEL, N.D., 2011. Effect of a neonatal low-protein diet on the morphology of myotubes in culture and the expression of key proteins that regulate myogenesis in young and adult rats. European Journal of Nutrition, vol. 50, no. 4, pp. 243-250. PMid:20827483. http://dx.doi.org/10.1007/s00394-010-0132-9.

OBEN, J.A., MOURALIDARANE, A., SAMUELSSON, A.M., MATTHEWS, P.J., MORGAN, M.L., MCKEE, C., SOEDA, J., FERNANDEZ-TWINN, D.S., MARTIN-GRONERT, M.S., OZANNE, S.E., SIGALA, B., NOVELLI, M., POSTON, L. and TAYLOR, P.D., 2010. Maternal obesity during pregnancy and lactation programs the development of offspring non-alcoholic fatty liver disease in mice. Journal of Hepatology, vol. 52, no. 6, pp. 913-920. PMid:20413174. http://dx.doi.org/10.1016/j. jhep.2009.12.042.

OLIVEIRA, T.W., LEANDRO, C.G., DEIRÓ, T.C.J., PEREZ, G.S., SILVA, D.F., DRUZIAN, J.I., COUTO, R.D. and BARRETOMEDEIROS, J.M., 2011. A perinatal palatable high-fat diet increases food intake and promotes hypercholesterolemia in adult rats. Lipids, vol. 46, no. 11, pp. 1071-1074. PMid:21847693. http://dx.doi.org/10.1007/s11745-011-3604-7.
OOSTING, A., VERKADE, H.J., KEGLER, D., VAN DE HEIJNING, B.J. and VAN DER BEEK, E.M., 2015. Rapid and selective manipulation of milk fatty acid composition in mice through the maternal diet during lactation. Journal of Nutritional Science, vol. 4, no. 19, pp. e19. PMid:26097702.

PEREZ, G.S., SANTOS, L.S., CORDEIRO, G.S., PARAGUASSU, G.M., ATHANAZIO, D.A., COUTO, R.D., DEIRÓ, T.C.B.J., MANHAES-DE-CASTRO, R. and BARRETO-MEDEIROS, J.M., 2015. Maternal and Post-Weaning Exposure to a High Fat Diet Promotes Visceral Obesity and Hepatic Steatosis in Adult Rats. Nutricion Hospitalaria, vol. 32, no. 4, pp. 1653-1658. PMid:26545531.

PURCELL, R.H., SUN, B., PASS, L.L., POWER, M.L., MORAN, T.H. and TAMASHIRO, K.L., 2011. Maternal stress and high-fat diet effect on maternal behavior, milk composition, and pup ingestive behavior. Physiology \& Behavior, vol. 104, no. 3, pp. 474-479. PMid:21605577. http://dx.doi.org/10.1016/j. physbeh.2011.05.012.

SAMPEY, B.P., VANHOOSE, A.M., WINFIELD, H.M., FREEMERMAN, A.J., MUEHLBAUER, M.J., FUEGER, P.T., NEWGARD, C.B. and MAKOWSKI, L., 2011. Cafeteria diet is a robust model of human metabolic syndrome with liver and adipose inflammation: comparison to high-fat diet. Obesity (Silver Spring, Md.), vol. 19, no. 6, pp. 1109-1117. PMid:21331068. http://dx.doi.org/10.1038/oby.2011.18.

SULLIVAN, E.L. and GROVE, K.L., 2010. Metabolic imprinting in obesity. Forum of Nutrition, vol. 63, pp. 186-194. PMid:19955786. http://dx.doi.org/10.1159/000264406.

TAMASHIRO, K.L., TERRILLION, C.E., HYUN, J., KOENIG, J.I. and MORAN, T.H., 2009. Prenatal stress or high-fat diet increases susceptibility to diet-induced obesity in rat offspring. Diabetes, vol. 58, no. 5, pp. 1116-1125. PMid:19188431. http:// dx.doi.org/10.2337/db08-1129.

TINOCO, S.M., SICHIERI, R., MOURA, A.S., SANTOS, F.S. and CARMO, M., 2007. Importancia dos acidos graxos essenciais e os efeitos dos acidos graxos trans do leite materno para o desenvolvimento fetal e neonatal, 2007. Cadernos de Saude Publica, vol. 23, no. 3, pp. 525-534. PMid:17334567. http:// dx.doi.org/10.1590/S0102-311X2007000300011.

WATERLAND, R.A., 2005. Does nutrition during infancy and early childhood contribute to later obesity via metabolic imprinting of epigenetic gene regulatory mechanisms? Nestle Nutrition Workshop Series Pediatric Programme, vol 56, pp. 157-171. Discussion pp. 71-74.

WORLD HEALTH ORGANIZATION - WHO, 2014. [viewed 10 June 2015]. Overweight and obesity. Available from: http:// www.who.int/gho/ncd/risk_factors/overweight_text/en/ 